\title{
The impact of changes in society on the use of languages
}

\author{
Djodjok Soepardjo \\ Universitas Negeri Surabaya \\ Surabaya, Indonesia \\ djodjoksoepardjo@unesa.ac.id
}

\author{
Warsono \\ Universitas Negeri Surabaya \\ Surabaya, Indonesia \\ warsono@unesa.ac.id
}

\begin{abstract}
Language as a means of communication undergoes some shifts or changes along with the changes of the society. This paper, therefore, seeks to explain some facts and look at the cause of language changes. The change in languages results from the internal and external factors of languages. In terms of external factors, the shift or change in the society is driven by such factors as communities, structures, and communication. Internally, language changes occur because new languages have emerged and old language has been forgotten and eventually lost. Specifically, changes initially take the form of a "misuse of words." If the misuse grows substantially, it becomes a mess / un-normative language. If users of un-normative language multiply, then the language is transformed. For example, in Japanese there is a change that the process can not be observed, but the results of these changes can be described by the theory of sociolinguistics.
\end{abstract}

Keywords: language changes, communication, loss of languages

\section{INTRODUCTION}

The most important essence of language is communication tool. As long as language functioned as a communication tool in society, then it must be affected by feelings, life style, and the speakers of the language's society tradition. The Japanese may be very surprised by the high frequency use on the French sign language [1].

The history of human life began simultaneously with the birth of language. For humans, as homo loquens, languages have a very important role to perform their activities. Before human beings is expressed as knowledge, homo sapiens, and as being the creator of the tool, homo fable, humans must master the language first. Because it is the language that stretches the dividing line between humans and other creatures.

As the time passed, the language also changed. Same as other countries, in Japan, the change of language can be an absolute thing. Someone who does not have knowledge of classical languages (kotengo), may not be able to read books that written in classical languages. Similarly, someone often finds difficulties to understand the language used by different generations. It means that the language moves dynamically in line with the changes in the community of native speakers. Because of this problem, many people who say the Japanese language today have been chaotic (midare). This phenomenon also occurred in Indonesia. Let us take the example of the language used in the Short Message Service (SMS). People who do not know the ways of writing SMS and not accustomed to reading it, often must use more effort to understand it. Here is an example of a message in a short message service (SMS).

1. Jangan q yg ksh tau mereka. Ntar d kiranya q yg btlin mreka gbs ikt eju, coz q yg promo k mreka, bkn susi.

2. quWh cuyyunk ummuwh kummuwh, tappih ammUwh cuwwug ujjuwh, aqquwh juddih buncciyh beudh ummuwh qummuwh, muufkund aqquwh kulluwh uqkuwh murruwh ummuwh qummuwh. (retrieved from Bahasa Alay level 5 website. (http://dzofar.com/ 2011/11/06/pembagianlevel-tulisan-alay/))

From the description above, it can be concluded that the shift or change in language is a necessity as well as changes in society. Any language, as long as the community is still alive and speakers are part of the cast of communication with other people, it will change continuously. The question is, what is going on when a language change? Why did it happen? In this paper, the authors will try to explain some facts and look at the cause of language changes.

\section{DISCUSSION}

\section{A. Change of Society}

The mean of change here is the change in society as a whole and not individually. To explain the change of society as a whole, it must be viewed holistically in the change of the community as a whole, ranging from class, hierarchy, occupation, national system, and communication systems that support the formation of a society. These major shifts must be captured as a change in the structure of a system on an ongoing basis for all aspects in a society, as a factor that causes immutability. 
There are three important factors in the shift or change in the community; communities, structures, and communication. All three of these factors can also result in extremes changes of decadence, irregularities, and conflict. Changes in society caused by human behavior within a community. The amendment is based on the mental attitude of the nature productivity. However, external factors such as elements of traditional community productivity, mental attitude, organizational capacity, ethnic diversity, economic downturn, and modernization have a significant effect on the change of society.

Meaningful action in change becomes a community activity which is then governed by the law of society itself. When it has become a part of society, it will cause problems in the community. Despite of that, community change is a sustainable aspect though basically in the society has its own defense system.

Associated with the theory of social change, it is mentioned that nothing is permanent, except the change itself. This indicates there is nothing in this world that can escape from the change. Thus, the existence of change is never passed by from the reality of human life, both as individuals and as society.

There is always a dynamic change in society life. Comte [2] said that a dynamic change is more important than a static thing even though both intended to discover the laws of social life because the pressure on the social change reflects the enormous attention to social reform. In this context, the social changes also affect the future of society as a life experience.

Changes is a very essential trait in the community. Therefore, the social changes that occur as a symptom generally occurs due to communication between the community and inform to absorb new ideas. Changes also occur because people began to tend to stop the research on the causes of absolute power (God or nature) and concentrated on observations of natural towards physical and social world in order to know the laws that govern them [2].

According to Hegel and Max [2], social change is accent reproduction to reproduce everything that is accepted as a cultural heritage of ancestors previously. Konosuke [3] illustrates that social change as a process of transformation which changes that occur naturally in a circle concept hatten seisei is born, grow, develop, and transformation. It is inseparable from human nature which basically has the qualities of curiosity, language and creatures that are capable of creating with the help of science and technology.

Globalization is a process leading to changes in the world community. Indonesia would not be able to block the process. In fact, today especially in big cities has arisen multicultural society.

Herbert Spencer [2] provided a solid model of society based on organism principles. An organism, according to Spencer, will grow perfectly if it gets more complex and the differentiation between the parts. Another section said that the society develops toward a state of moral ideal and more perfect. In fact, he added that the people who are best able to adapt to their environment who will survive, while people who are not able to adjust to forced doomed. The result of this process is to improve the ability to adjust to society as a whole.

Society as an organism has its own criteria: the complexity, differentiation, and integration. The criteria will be applied to every community. The social assessment and social development basically means increasing the differentiation and integration, improved division of labor and a transition from a homogeneous state to a heterogeneous state.

Multicultural society in this sense is a process in which practi-social practices and patterns of interaction are governed by the rules and the role of members of the public with this rich diversity, recognized, respected in the packaging of engagement with the interactions and dynamics. Multicultural society is also understood as Bedahan, studies, and research paper on color diversity of cultural, social transformation, and the dynamics of the national culture in the global era.

\section{B. Sociolinguistic}

Sociolinguistics is a branch of linguistics that studies the essence of language and its function in society. Since the advent of structuralism flow, the researchers realized that the language is a public institutions, which is a symbol system sounds and patterns of the relationship between these symbols. Language is the most advanced means of communication between these communication tools used by humans. In relation to the language as a means of communication in the community under study there are at least 3 aspects; (1) the influence of society on language; (2) the function of language in society; (3) the reality of language use in society [4].

Language study focused on the influence of language in society, generate knowledge of language variation and language diversity. Variations language is very closely linked to the internal factors of language and it can be explained by linguistic. While external factors located outside the language because it is associated with and regulated by factors in society generally studied by linguists sociological namely sociolinguistic [4].

Nababan [4] divides the variations that go beyond language into four factors, namely; (1) geographic factors or origin of speakers; (2) factors speakers sociological or social groups; (3) factors of language function; and (4) factors over time, ie the time of his life speakers. Four factors external to the language variations affect the language shift.

The object of study of sociolinguistics is language as parole. Language as parole is seen as device behavior that has been culturally transmitted or used by a group of individuals in society. The outlook seems to have an understanding that language as a human cultural behavior. Thus humans could not exist without the presence of the language so does human social interaction and communication always use the language.

Furthermore, Jendra [5] says that in sociolinguistic speakers also as source of repertoire language that has feelings, thoughts, and behavior of language. Three elements (feelings, thoughts, behaviors language) is a 'society that does not always have the feature that is consistent in language development. Many communities do not care about the language, but there are also people really closely united, proud, and always uphold the language as group pride or pride of the nation.

Associated with the changes in language, Saussure [6] and Bloomfield [7], explains that the language change can not be observed. But the consequences of the change of change itself is likely to be observed.

As already described, the language changes according to experts could not be observed, this is due to the process of change happening takes place in a relatively long time, so it may not be observed by the researchers. Nevertheless, as described Chaer [8], evidence for the language change can be known for that language literary tradition and written documents of the past. 
Changes can occur at all levels of linguistics, such as: phonology, morphology, syntax, vocabulary, semantics. These aspects are seen in the language changes including changes in rules, can increase, decrease, or the emergence of new rules. Changes can also occur due to the absorption of other related language or a foreign language. As a result of the influx of foreign words often changes the form of words to conform with the rules of the receiving language.

As previously described sociolinguistic observes changes in language in the form of the variation of the language and the use of language in society. The results of these observations may be taken into consideration to help understand the existence of a change in a language.

\section{CHANGES IN JAPANESE}

Young people today often use "language without ra" or $r a$ nukikotoba. Many Japanese complain "indeed young people now has gone too far." You hear the sound of sadness as well, and indeed "can now be used". Initially people -the parents complain but now everyone is using. If you're even a little, the parents to have or use. the problem is whether this is a creasing / chaos in the language? or is it a transformation language? the language of life, will change constantly. Changes first, starting as a "misuse of words." If the wrong number had grown much, it becomes a mess / un-normative language. If users of unnormative language is multiply then it means the language is transformed. "the use of the correct language" is use the results of the convention speakers, 15 or 16 years the experts tried to rectify or stressed-out verb usage errors duck without the "ra" to express the form can, but now everyone is using these forms. "Taberareru" to "tabereru" "mirareru" to "mireru" and so forth. The use of the verb tan "ra" to express the shape can be, because it has been used almost everybody, even in grammar or viewed from the sense of wrong, apparently because it has become a convention entire Japanese speakers are now allowed to be the correct language. Similarly from Fator accent, the Japanese tend to say flatly or heibanshiki. So, it is the nature of language, as long as the language is used as a communication tool, it will continue to change.

There are languages that will never change, namely Latin. Latin was used as the language in Vatican, used and studied but not used as a communication tool. The language was dead because it will not change. The language changes and makes speakers uncomfortable will usually disappear on their own.

Previously, people in the Meiji era struggled when going to use a concept borrowed from abroad. The word "economy"ditrjemahkan originally keiseisaimin「経世済民」 , the word is now becoming Keizai「経済」. Yukichi Fukuzawa never makesaid ennzetsu「演説」 for people who want to have the ability to make a speech convey his ideas in front of the crowd. Then he set up a building on the university campus Keio used to train people who want to hone the skills of oration. Until now, the building is still standing strong and named enzetsukan 「演説館」.

Today, authors often hear the statement that the language of young people in Japan have chaos. Actually, issue like this is not new. Because if we traced further back, before the war or in the Meiji era, even since the Heian era, the statement already exists.

As it has been known that the language equated with living creatures, and the language changes. As evidence that the language is changed, can be proved by reading the original text Genji Monogatari Murasaki Shikibuwork. Can you understand it? Then, compare the language also found in literature ranging Kamonochomei era, Chikamatsu Monzaemon, Mori Ogai, Ryotaro Shiba, until the work of Banana Yoshimoto, then it will be known that the language is changing. The question is, why languages change?

Language changes occur due to new languages appeared and old language has been forgotten and eventually lost. Why does the new language, and the old language gone? The are many causes as mentioned in the introduction. The factors that cause changes in language can be broadly divided into two namely due internal factors of language and external factors of language.

Furthermore, the authors show the results of a survey of the changes in the Japanese language. The survey was conducted by NHK Houso Kenkyuusho March 2013 with the theme Nihongo no yure Chousa (Survey of Japanese Language Disorder). The total sample consisted of 1,241 people male and female. Age of the sample above 20 years old and were asked to answer 39 questions in the form of a questionnaire. The author will not be present all the results of the survey, but choose the most easily understood aspect to prove that the language continues to change. Most of the survey results as beriku;

1. One quarter of the sample said that, consideration the use of kyaku or okyaku in the news highly dependent on the substance of the news.

2. The verbs if mireru, tabereru, began to use the end of 1800 and began to be felt there were irregularities in the use of 1940 's. In 1980 a polemic with the specified name nuki kotoba ra.

3. Towards the question whether the pronunciation of verbs taberenai felt strange or not? The answer is very different depending on the educational history of the sample. Samples that were young said didn't feel any strangeness even though they use the verb ra nuki,but as getting older, they feel the incongruity.

4. Regarding opinions about the use of Japanese in NHK, and the realization that the Japanese increasingly chaotic, the age difference is very clear.

5. From the survey results can be estimated that there are still people who do not want to use the verb ra nuki the NHK broadcast despite his own use.

From the foregoing, it is clear that in Japanese there is a change that the process can not be observed, but the results of these changes can be described by the theory of sociolinguistics.

\section{CONCLUSION}

When scrutinize the description above, it can be concluded that a shift or change in language is a necessity as well as a change in society. Therefore, any language as long as the community is still alive and speakers are part of the cast of communication with other people, he will continue to change. Changes a very essential trait in the community. Therefore, social change is a symptom that occurs generally due to take place in the communication between the community and inform to absorb new ideas. Because language as a means to convey the idea, then the language also helped the change. These aspects are seen in the change of language covering all levels of linguists including changes to the rules, and its use in the community. Real example is the use of the verb ra nuki in the lives of the Japanese language. 


\section{REFERENCES}

[1] M. Keizaburo, "Kotoba To Wa Nanika Natsumeshobou", 1995.

[2] G. Ritzer and D. J. Goodman, "Sociological Theory Modern”, translated by Aliman. Jakarta: Kencana, 2012.

[3] M. Konosuke,"Thoughts About Men", Jakarta: Pustaka Jaya, 1997.

[4] P. W.J. Nababan, "Sosiolinguitik: An Introduction", Jakarta: Gramedia, 1984.

[5] I. W. Jendra, "Sociolinguistic Theory and Practice", Surabaya: Paramita, 2007.

[6] F. de Saussure, "Course de Lingustique Generale", Translated into Indonesian by Rahayu S. Hidayat and edited by Harimurti Kridalaksana. Yogyakarta: Gadjah Mada University Press. 1996.

[7] L. Bloomfield, "Language", New York: Holt, Rinehart and Winston, 1933.

[8] A. Chaer, dan A. Leonie, "Sosiolinguitik", Jakarta: Rineka Reserved, 2004. 